\title{
非接触センサを用いた高サイクル疲労診断システムの開発*
}

\author{
猫 本 善 続*1, 田中将 憲*2, 西 村 護 達*2 \\ 松 本 健 次*3, 大島榮 次*4
}

\section{Development of a High Cycle Vibration Fatigue Diagnostic System with Non-contact Vibration Sensing}

\author{
Yoshitsugu NEKOMOTO*5, Masanori TANAKA, Moritatsu NISHIMURA, \\ Kenji MATSUMOTO and Eiji O'SHIMA
}

\footnotetext{
${ }^{* 5}$ Takasago R \& D Center, Mitsubishi Heavy Industries, Ltd.,

2-1-1 Shinhama, Arai-cho, Takasago-shi, Hyogo, 676-8686 Japan
}

\begin{abstract}
Nuclear power plants have a large number of pipes. These small-diameter pipe branches in particular are often damaged due to high-cycle fatigue. In order to ensure the reliability of a plant it is important to detect fatigue damages in pipe branches at an early stage and to develop the technology to predict and diagnose the advancement of fatigue. Further, in order to carry out the diagnosis of the piping system effectively during operation, non-contact evaluation is useful. Hence, we have developed a "high-cycle fatigue diagnostic system with non-contact vibration sensing", which measures the vibration of the pipe branch using a non-contact sensor.
\end{abstract}

Key Words: Fatigue, Diagnostics, Life Prediction, High Cycle Vibration, Laser Vibrometer, Pipe Branch

\section{1. はじめに}

原子力プラントにおける主要構成機器は回転機械, 配管, 熱交換器, 弁等で構成され, その中でも配管は 物量的にかなりの範囲を占めている。これらの配管系 に関する原子カプラントの稼働率向上，および合理的 管理を行うためには, 広範囲に分布する対象配管を容 易に監視診断する技術が必要である，そこで，これま での不具合事例等を調査検討した結果, 高サイクル疲 労による損傷例が多い小口径分岐管を対象に; 運転中 に作業員が入室することが困難であり, また, 被曝低 減の観点から放射性管理区域 (ループ室内) の配管に着 目して疲労監視診断システムを構築した。

配管系の疲労評価を行う既存システムについて, 多 くは接触型センサ用を用いたシステムであり, 計測に 多大な時間が必要であった(1) (5). そこでプラント運 転中に効率的に計測する技術としては非接触センサが

* 原稿受付 2003 年 12 月 12 日.

*1 正員, 三菱重工業(株) ( 676-8686 高砂市荒井町新浜 2-11).

*2 三菱重工業(株).

*3 九州電力 (株) ( 810-8720 福岡市中央区渡辺通 2-1-82).

*4 東京工業大学資源化学研究所( 226-8503 横浜市緑区長津 田町 4259).

E-mail : yoshitsugu_nekomoto@mhi.co.jp
有効であることから，センシング部にレーザや光ファ イバ応用技術を適用し, 非接触にて振動計測を行うシ ステムを構築した。本システムでは，コンピュータ内 に対象分岐管の振動特性を模擬した解析モデルを作成 し，センシング部で得られた振動データをもとに解析 モデルを介して分岐管の発生応力, 疲労が評価, 診断 される。

本システムの接触センシング部は, 将来的にはモ， レールによりプラント各部の分岐管を目標として移動 するシステムを想定しており，本論文はプロトタイプ として開発した固定式非接触方式による小口分岐管高 サイクル疲労診断システムの内容について記述したも のである.なお, 本システムの開発は, 財団法人(旧) 発電設備技術検査協会が経済産業省の委託を受けて実 施したものである.

\section{2. システム概要とセンシング部}

$2 \cdot 1$ システム構成 小口径分岐管の非接触高サ イクル疲労診断システムの構成を図 1 に示す。システ ムはセンシング部と診断・評価部から構成され，セン シング部はセンサヘッドと信号処理部から構成され る. センシング部で検出された分岐管の振動信号は光 ファイバケーブルによって診断部に伝達され, 解析評 
価，診断が行われる。

\section{$2 \cdot 2$ 非接触センシング部}

$2 \cdot 2 \cdot 1$ 面外振動の計測 (ドップラー振動計)

a. 計測原理

システムでは, 評価精度の向上を目的として, 分岐 管の面外振動と面内振動が計測され, 面外振動の計測 にはドップラー振動計を採用した。

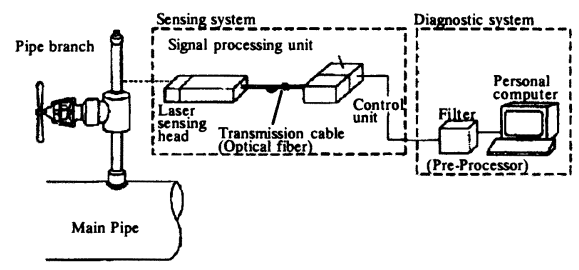

Fig. 1 Overview of the whole diagnostic system

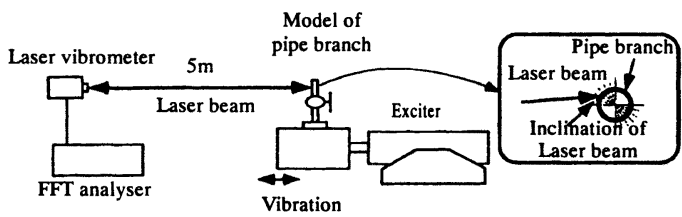

Fig. 2 Test configuration of adaptability of laser vibrometer to model of pipe branch

\section{b. 機能確認試験}

実機プラントにおける分岐管を計測する際, 分岐管 の振動方向と, ドップラー振動計のレーザ方向を一致 させること (レーザ入射角 $\left.0^{\circ}\right)$ は, プラント配置上困難 な場合が多く, ある程度の入射角を許容する必要があ る.

そのため, システムの実用性, 有用性を検証する確 証試験に先立ち, センシング部について面外, 面内同 時計測による性能確認試験を実施し, センシング部の 適用限界を明確にした。面外振動計測部の試験概要を 図 2 に示す。試験対象には, パイプ状試験体を用い, センシング部と分岐管の計測距離は実用上必要である $5 \mathrm{~m}$ とした。入力波にはランダム波に分岐管の卓越振 動数成分(正弦波 $50 \mathrm{~Hz}$ ) を重ね合わせた波を使用し, 卓越成分の正弦波が検出できるか否かにて検出性能を 評価した. 入力波 (試験体加速度) と検出波の周波数分 析結果をレーザ入射角をパラメータとして図 3 に示 す.

図 3 の計測結果より，入射角 $25^{\circ}$ までは正弦波の卓 越成分は検出可能であり, 面外振動計の適用限界は 25 以内とした。

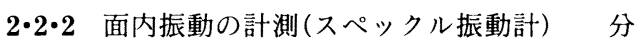
岐管の面内方向振動については,ドップラー方式とス

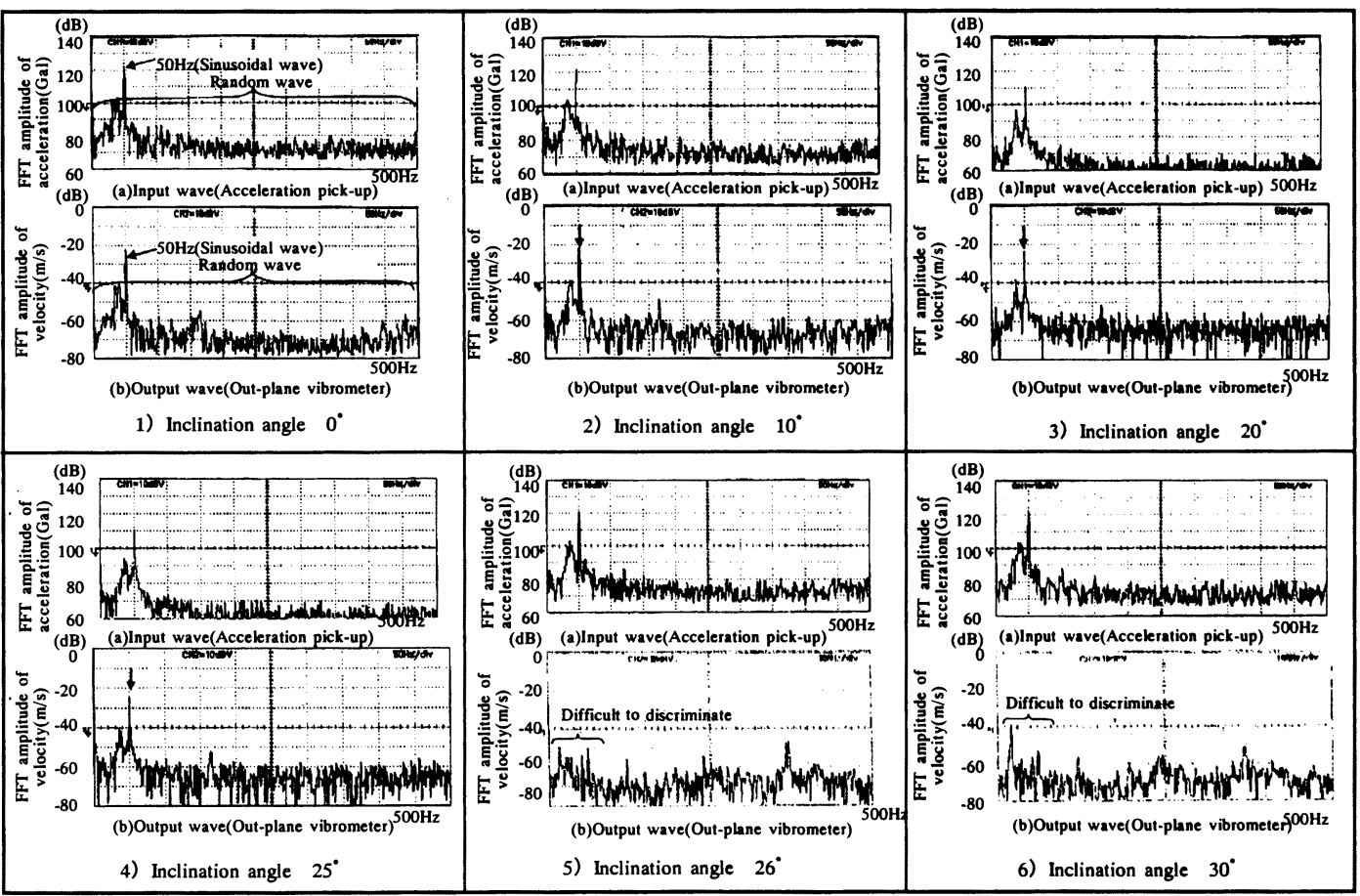

Fig. 3 Test results of the out- ${ }^{-}$-plane vibrometer for inclination of pipe branch 
ペックル方式を検討したが，面内方向(レーザ直角方 向)の振動については,ドップラー方式はミラーが必 要となるなど、スペックル方式に比較して計測装置が 大形化するため, 装置の小形化が可能なスペックル方 式を採用した。

スペックル方式の原理を図 4 に示し, 装置構成を図 5 に示す、スペックルとは、レーザ光を対象面に照射 した場合，反射光中に生じる不規則な斑点模様のこと であり、これは粗面で不規則に反射された光が干涉し て生じるものである。刘称面(分岐管表面)が移動した 場合, スペックル強さも移動速度に比例して変化する ため、そのスペックル強さの変化を検出することによ

ク、振動速度を算定するこができる(6).

スペックルオ式の面内振動計測部についても面外の ドップラー振動計同様に性能確認試験を実施し, 面内 振動計測の適用限界は 15 以内とした。

\section{3. 診 断 部}

$3 \cdot 1$ 診断部の構成 診断部のシステムフローを 図 6 に示す。診断部はデータ・ロガ部と解析・評価部 から構成される。データ・ロガ部では, 分岐管の振動 速度データが集録, 分析される。解析・評価部では, 主に分岐管の解析モデルを作成して, 応力と速度応答 の関係(周波数応答特性) を算出するモデル設定部と， データ・ロガ部で求められた速度デー夕(周波数分析 結果)をもとに発生応力を推定して疲労評価を行う応 力・疲労評価部に分けられる。

$3 \cdot 1 \cdot 1$ データ・ロガ部 データ・ロガ部では,

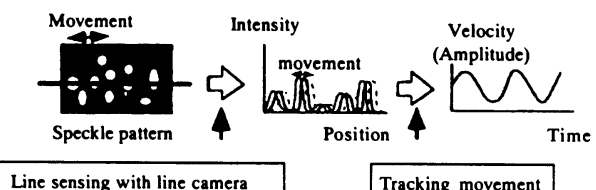

Fig. 4 Principle of laser in plane vibrometer with laser speckle method and motion tracking

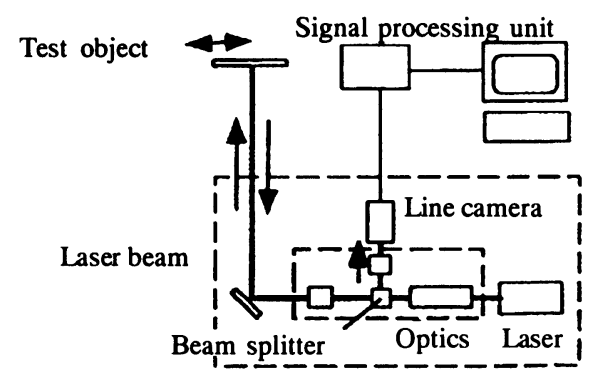

Fig. 5 Configuration of laser in plane vibrometer
対象分岐管の非接触センサからの観測記録(速度デー 夕)が集録され，得られた速度時刻歷波形は周波数分 析され,データベースとして保存される。

$3 \cdot 1 \cdot 2$ 解析・評価部 モデル設定部では, 応答 解析, 疲労評価に用いられる解析モデルが作成され る.また，作成された解析デルを用いて固有值解析を 行い, 振動数, 振動モードが求められ, 振動モードを もとに発生応力と応答の関係 (周波数応答特性) が算出 される.

応力・疲労評価部では, データ・ロガ部で集録, 分 析された分岐管の速度応答の周波数分析結果, および モデル設定部で算出された応力と応答の周波数特性か ら分岐管基部の発生応力が推定され, 分岐管の累積疲 労評価, 診断が行われる.

\section{$3 \cdot 2$ 診断アルゴリズム}

$3 \cdot 2 \cdot 1$ 発生応力の推定

a. 応力と応答の周波数特性 $J(\omega)$

非接触振動計測法により計測した分岐管の振動速度 から, 分岐管の応力を推定する手法のフローは図 6 に も示したように, 以下のように求められる.

図 6 において, 応力と応答の伝達関数 $J(\omega)$ が既知 であるとすると, 計測した振動応答(速度) から分岐管 の発生応力は次式により求められる.

$$
\begin{aligned}
& \sigma(\omega)=v(\omega) \cdot J(\omega) \\
& \quad=v(\omega) \cdot H(\omega) / G(\omega) .
\end{aligned}
$$

$$
\text { ここで, }
$$

$\sigma(\omega)$ : 発生応力 $\sigma(t)$ の周波数特性 (フーリエ変換)

$v(\omega)$ : 分岐管の振動応答計測デー夕 $v(t)$ の周波数 特性(フーリ工変換)

$J(\omega)$ : 分岐管基部応力と応答の伝達関数

$H(\omega)$ : 分岐管基部応力と力の伝達関数

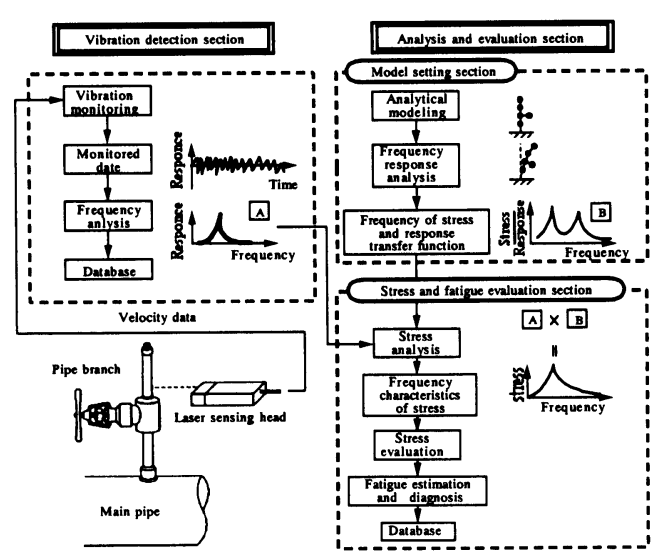

Fig. 6 The diagnostic system flow 
$G(\omega)$ : 分岐管応答と力の伝達関数

つまり, 以下の手順で計測した分岐管の振動応答 (速度)から分岐管の応力が推定される.

（1）評価対象の分岐管について解析モデルを作つ て, 母管に振動を与えた場合の振動応答の伝達関数 $G(\omega)$, および応力の伝達関数 $H(\omega)$ を求める.

（2）求めた応力の伝達関数 $H(\omega)$ と応答の伝達 関数 $G(\omega)$ から, あらかじめ応力と応答の伝達関数 $J(\omega)$ をモデル設定部で用意する.

(3) データ・ロガ部で分岐管の応答 $v(t)$ が集録 され，そのフーリエ変換 $v(\omega)$ が求められる.

(4) 応力・疲労評価部で, 分岐管の応答 $v(\omega)$ と, 応力と応答の伝達関数 $J(\omega)$ の積から, 発生応力の周 波数特性 $\sigma(\omega)$ が算出される.

(5) 発生応力の周波数特性 $\sigma(\omega)$ より, 応力レベ ルと振動数 (回数) から累積疲労が求められる.

b. 応答の伝達関数 $G(\omega)$

固有値解析結果をもとに, $r$ 次モードにおける $i$ 点 に作用する外力と $k$ 点の変位の間の伝達関数 $G i k_{r}$ を 求める. 伝達関数 $G i k_{r}$ は以下のように表される.

$$
\operatorname{Gik}_{r}(\omega)=\frac{A i r A k r}{K r} \frac{1}{1-\left(\omega / \omega_{r}\right)^{2}+j 2 \zeta_{r} \omega / \omega_{r}}
$$

ここに,

$r:$ モード次数

$i:$ 作用外力節点

$k:$ 変位応答の節点

$\omega_{r}: r$ 次の固有円振動数

$\zeta_{r}: r$ 次の減衰比 $\left(\zeta_{r}=0.01\right.$ とする $)$

$j^{2}:$ 複素数 $=-1$

Air $: r$ 次の節点 $i$ の一般座標振幅

$K_{r}: r$ 次のモード剛性 $=\{A r\}^{T}[K]\{A r\}$

$\{A r\}: r$ 次の一般座標

$[K]$ : 剛性マトリックス

また, $r$ 次モードの外力と応答の位相差は次式のよ うに表される.

$\tan \left\{G i k_{r}(\omega)\right\}=\operatorname{Im}\left\{G i k_{r}(\omega)\right\} / \operatorname{Re}\left\{G i k_{r}(\omega)\right\}$

ここで, 作用荷重の作用点 $i$ は, 母管(固定端)から いちばん離れた弁の集中質量の節点とした。

したがって, $r$ 次振動モードごとに, 各点の周波数 応答が求められる。

また, 1 〜 次までの伝達関数を重ね合わせること により, 伝達関数 Gik が求まる.

$$
G i k(\omega)=\sum_{r=1}^{n}\left\{G i k_{r}(\omega)\right\}
$$

ここに, $n=$ 最高次数 $(400 \mathrm{~Hz}$ までのモード $)$

c. 応力の伝達関数 $H(\omega)$

各 $r$ 次のモードについて, 各点の伝達関数 $G i k_{r}$ (応 答変位を表す) と位相 $\tan \left\{G i k_{r}(\omega)\right\}$ から, 各 $r$ 次モ一 ドにおける応答変位が定まるため, $r$ 次モードに対応 する分岐管基部で発生する応力の周波数応答が求めら れる。

求められた各モードの応力の伝達関数 $H_{r}(\omega)$ を重 ね合わせるとにより, 伝達関数 $H(\omega)$ が求められる.

$$
H(\omega)=\sum_{r=1}^{n}\left\{H_{r}(\omega)\right\}
$$

したがって, 応答の伝達関数 $G i k(\omega)$ と, 応力の伝 関数 $H(\omega)$ の比 $H(\omega) / G i k(\omega)$ より, 計測点 $(k=m)$ における応答と応力の伝達関数 $J(\omega)$ が求められる.

$$
\begin{aligned}
& J(\omega)=\frac{H(\omega)}{G i k(\omega)} \\
& i \text { :母管より最も離れた弁の節点 } \\
& k \text { : 計測点 }
\end{aligned}
$$

$3 \cdot 2 \cdot 2$ 疲労損傷の推定 求められた応力の周波 数特性より, 応力レベル, 周波数 (回数) から, 以下に 示す Minerの累積疲労損傷度の式を用い, プラント 運転デー夕時間をもとに累積損傷度 $\alpha$ を算出する.

$$
\alpha=\sum_{i=1}^{m} \frac{n_{i}}{N_{i}}
$$

ここに,

$n_{i}$ : 応力振幅 $a_{i}(i=1 \sim m)$ の発生回数

$N_{i}$ : 応力振幅 $a_{i}(i=1 \sim m)$ に対する許容繰返し 回数

疲労損傷度の算出に用いる疲労曲線は ASME 曲線 と金属材料研究所のデー夕を用いる(7)(8). また, 評価 においては，発生応力を疲労限と比較するとともに， 発生応力が疲労限を越える場合には累積疲労損傷 $\alpha$ に基づく診断を実施する( $\alpha \geqq 1$ で損傷)。

\section{$3 \cdot 3$ 診断システムの入力と出力}

\section{$3 \cdot 3 \cdot 1$ 入力デー夕}

\section{a. モデル設定部}

モデル設定部では，計測データから診断を実施する ための解析モデルの設定を行う. 分岐管をはり要素と してモデル化し，母管との境界条件を回転ばねでモデ ル化する、サポートがある場合はサポートの剛性をば ね要素でモデル化する.

入力データの画面例を図 7 に示す.

b. 応力・疲労評価部

応力・疲労評価部では疲労損傷推定のため, テーブ ルとして準備された材料の $S-N$ 曲線とともに, プラ ント運転データを入力する必要がある.

$3 \cdot 3 \cdot 2$ 出力結果 応力・疲労評価部では評価結 
果として分岐管基部の発生応力, 蓄積疲労損做が出力 される. 出力結果の画面例を図 8 に示す.

\section{4. 確 証 試 験}

$4 \cdot 1$ 対象分岐管の選定と試験モデル 高サイク ル疲労診断システムの実機への適用性, 有用性を検討 するため, 実機を想定した分岥管を対象に振動台を用 いた確証試験を実施した。試験条件を決定する際, PWR 形実機プラントのループ室内分岐管について三

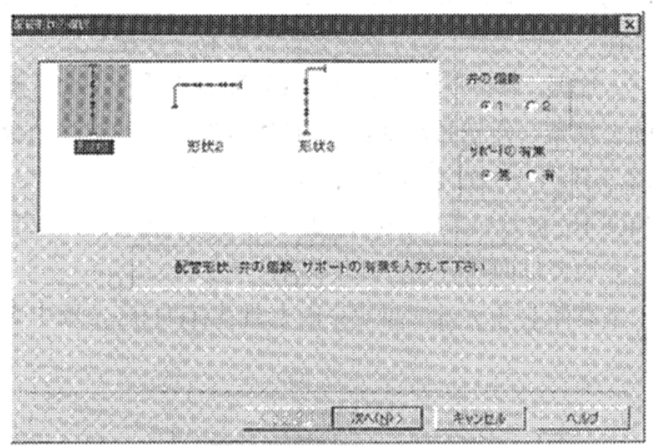

(a) Selection of pipe branch shape

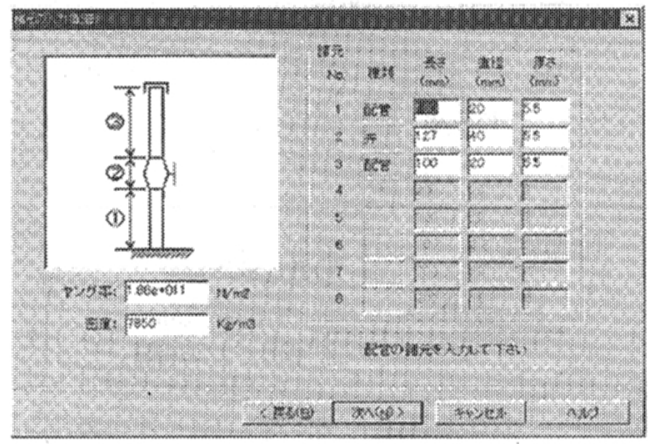

(b) Input of stractural and material data

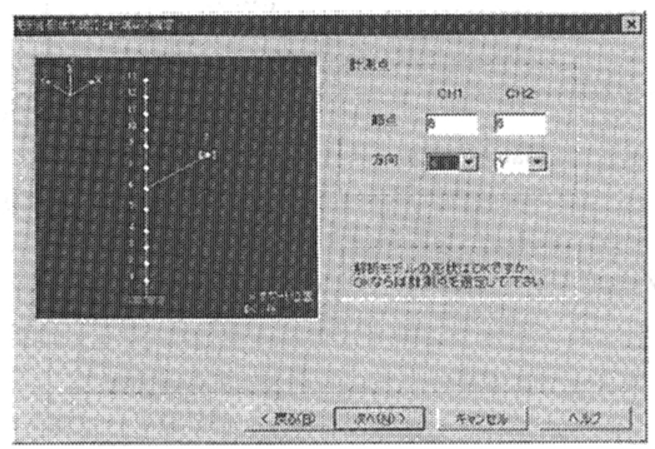

(c) Analytical model

Fig. 7 Input data screen examples of the diagnostic system
次元 CAD データを利用してセンシング部の分岐管へ のアクセス条件を検討した。

センシング部の移動手段としては図 9 に示すように モノレールを想定し, センシング部から分岐管までの 距離を $5 \mathrm{~m}$ 以内, レーザの分岐管への入射角が機能確 認試験にて確認済の $\pm 15^{\circ}$ 以内にできるようにルート を選定した.

実機分岐管形状は図 10 の 3 タイプであり, 分岐管 とレールとの距離も $5 \mathrm{~m}$ 以内で充分計測可能である ことがわかった。レーザの入射角は大半が $\pm 15^{\circ}$ 以内

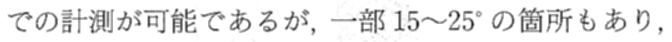
$15^{\circ}$ 以上の計測の可能性については, 確証試験におい て確認することとした.

これらの調査結果より, 構造パラメータ(母管直径, 分岐管形状, 弁個数, 管台種類ほか) をもとに実機分岐 管を 9 種類に分類し, 確証試験では図 11 に示すよう に, 代表的な 4 種類について試験を寒施することとし た.

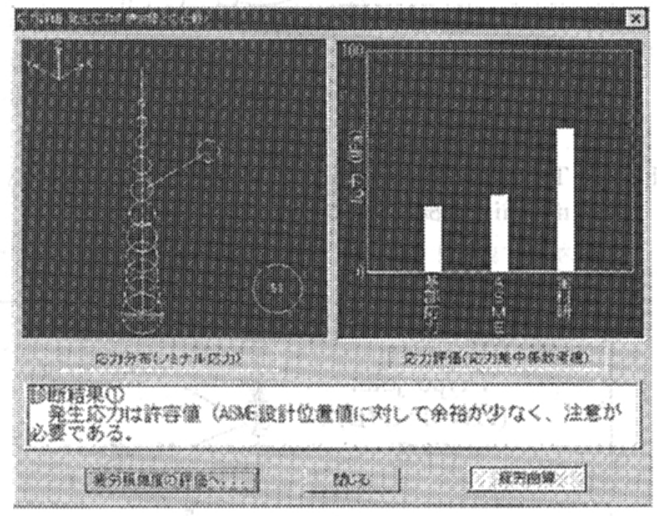

(a) Results of stress analysis

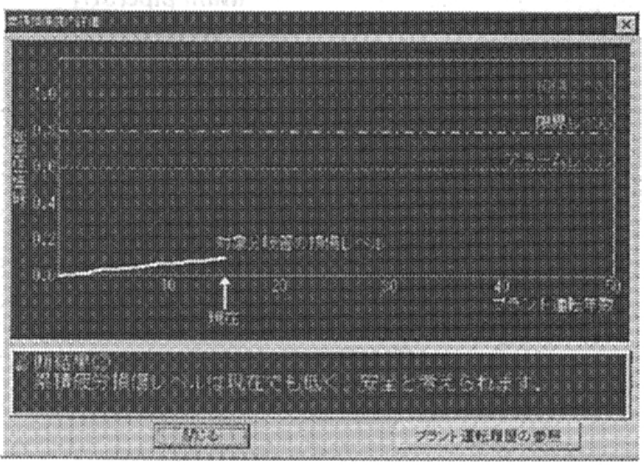

(b) Estimation results of fatigue

Fig. 8 Estimation results screen examples of the diagnostic system 
$4 \cdot 2$ 試験内容 試験は図 12 に示すように, 実機 分岐管を模擬した試験モデルを振動台試験上に設置 し，母管振動を模擬した入力波により振動試験を実施

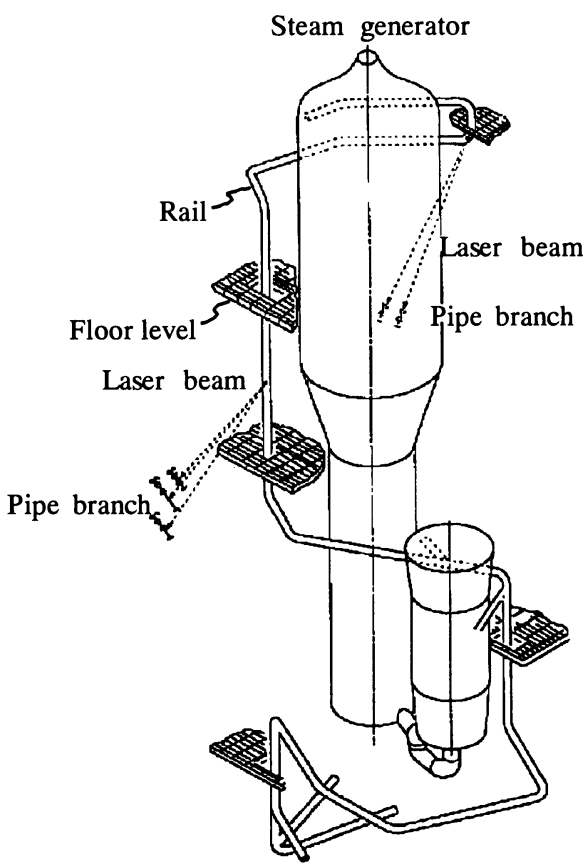

Fig. 9 Transportation means of sensing system by nonrail in SG room
した. 非接触センシング部で計測されたデータをもと に診断システムで推定した発生応力の推定精度を検証 するため, (1) 従来の接触式である加速度計を用いて データを取得し, 解析モデルを介して推定した応力お よび( 2 )ひずみゲージで計測された発生忍力と比較, 検討を行った。なお，応力集中を考慮した発生応力は 分岐管基部において最大となることから、比較評価は 分岐管基部応力について行った，

$4 \cdot 3$ 試験結果 試験結果の一例として, M 3 モ デルの試験結果を示すＭ３モデルは，ねじり振動の 卓越する比較的振動性状が複雑なモデルである。人力 加振については，（1）ランダムな脈動を模擬したラン ダム加振, および ( 2 ) 卓越する周波数成分を有する脈 動を模擬した正弦波加振 (卓越周波数は分岐管振動数 $72.5 \mathrm{~Hz}$ に一致)を行った。また，試験は、（1）センサ 角度 $15^{\circ}$ においては面内・面外計測を実施し，(2) 25 においては面外計測のみを実施した。

本診断システムで推定された発生忍力(応力集中を
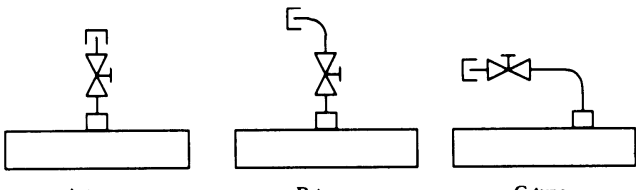

C-type

Fig. 10 Type of pipe branch

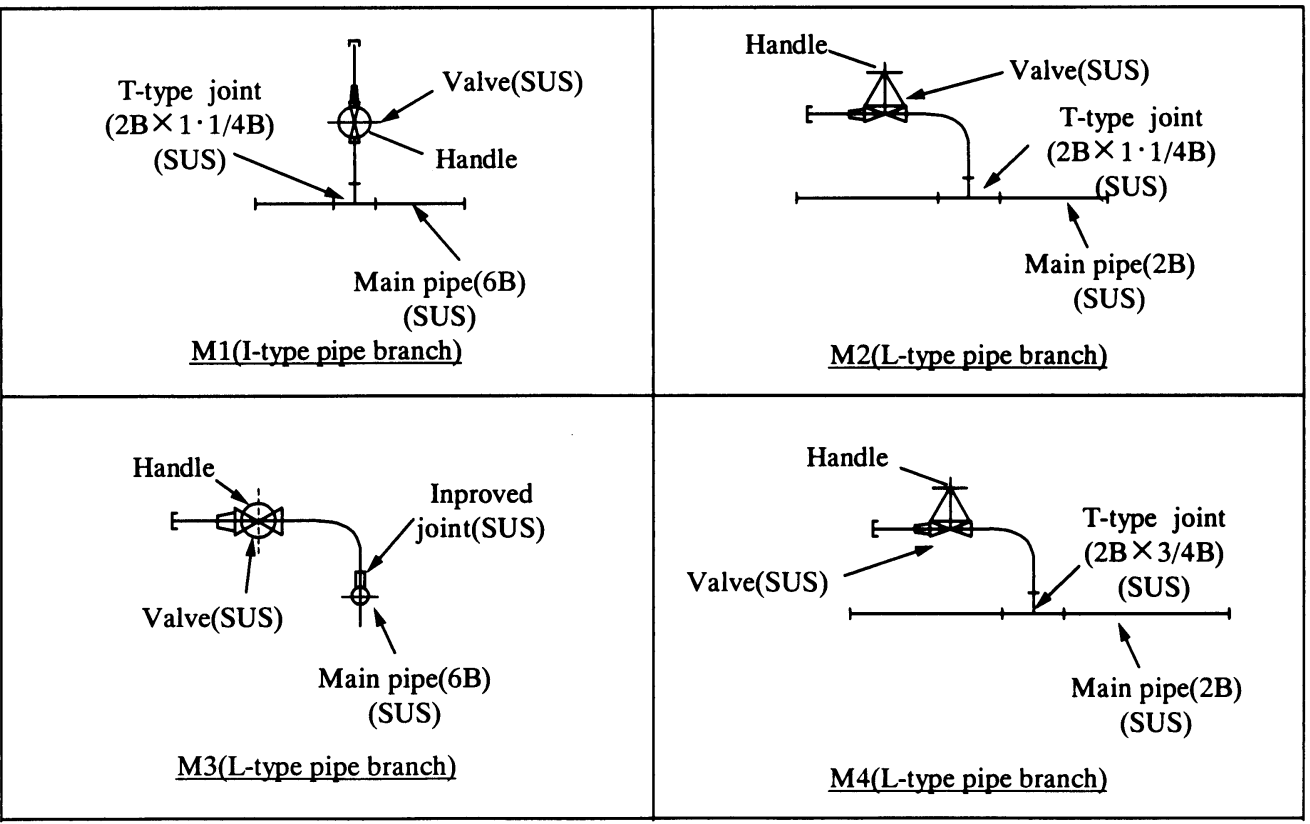

Fig. 11 Test model 
Table 1 The test result of estimated stress (M 3 model)

\begin{tabular}{|c|c|c|c|c|c|c|c|c|c|c|}
\hline \multirow{3}{*}{ Case } & \multicolumn{2}{|c|}{ Input condition } & \multicolumn{5}{|c|}{ Diagnostic system } & \multicolumn{2}{|c|}{$\begin{array}{c}\text { Conventional } \\
\text { system }\end{array}$} & \multirow{3}{*}{\begin{tabular}{|c|}
$\begin{array}{c}\text { Strain } \\
\text { gange }\end{array}$ \\
\\
Measured \\
stress \\
(MPa)
\end{tabular}} \\
\hline & \multirow[b]{2}{*}{ Input wave } & \multirow[b]{2}{*}{ Level } & \multicolumn{2}{|c|}{$\begin{array}{c}\text { Measurement } \\
\text { condition }\end{array}$} & \multicolumn{2}{|c|}{$\begin{array}{c}\text { Measured } \\
\text { velocity }\end{array}$} & \multirow{2}{*}{$\begin{array}{c}\text { Estimated } \\
\text { stress } \\
\text { (MPa) }\end{array}$} & \multirow{2}{*}{\begin{tabular}{|c|} 
Measured \\
acceleration \\
(G)
\end{tabular}} & \multirow{2}{*}{\begin{tabular}{|l} 
Estimated \\
stress \\
(MPa)
\end{tabular}} & \\
\hline & & & $\begin{array}{c}\text { Distance } \\
(\mathrm{m})\end{array}$ & $\begin{array}{c}\text { Inclination } \\
\text { angle } \\
\text { (c) }\end{array}$ & $\begin{array}{c}\text { Out-of- } \\
\text { plane }\end{array}$ & $\begin{array}{c}\text { In- } \\
\text { plane }\end{array}$ & & & & \\
\hline M3-1 & $\begin{array}{l}\text { Random } \\
\text { wave }\end{array}$ & 0.5 & 5 & 15 & 2.8 & 0.8 & 3.7 & 1.32 & 3.6 & 3.27 \\
\hline M3-2 & $\begin{array}{c}\text { Sinusoidal } \\
\text { wave }\end{array}$ & 0.06 & 5 & 15 & 6.4 & 1.8 & 8.5 & 3.38 & 9.2 & 8.26 \\
\hline M3-3 & $\begin{array}{c}\text { Random } \\
\text { wave }\end{array}$ & 0.5 & 5 & 25 & 2.5 & - & 3.5 & 1.38 & 3.8 & 3.22 \\
\hline M3-4 & $\begin{array}{c}\begin{array}{c}\text { Sinusoidal } \\
\text { wave }\end{array} \\
\end{array}$ & 0.06 & 5 & 25 & 6.0 & - & 8.5 & 3.31 & 9.0 & 8.20 \\
\hline
\end{tabular}

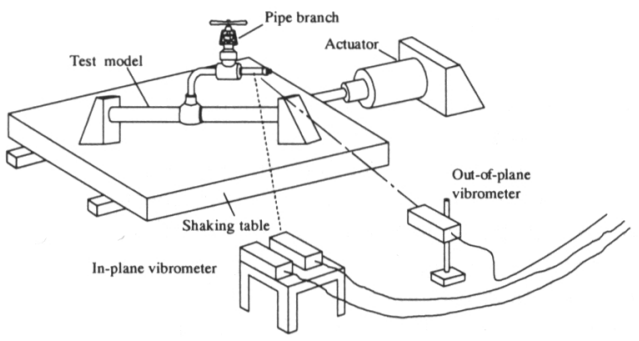

Fig. 12 Overview of the verification test

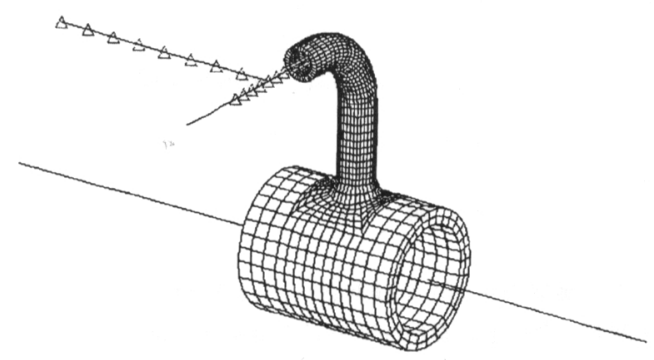

Fig. 13 Analytical solid model (M 3 model)

考慮しない公称応力)を, 計測された速度応答ととも に表 1 に示す。比較のため, (1) 従来の接触式加速度 計の計測結果を基に, 汎用構造解析ソフトにより解析 モデルを介して求められた発生応力, および( 2 )ひず みゲージで計測された発生応力を同表中に示す。接触 式加速度計のデータを基に応力を推定する際に用いた 解析モデルを図 13 に示す。

表 1 の発生応力の内，ランダム加振抢よび正弦波加 振時のセンサ角度 $15^{\circ}$ (面内・画外同時計測)，および センサ角度 $25^{\circ}$ (面外計測) の発生応力を各評価手法で 比較して図 14 に示す。

図 14 より, 本診断システムを用いて推定された応 力は, 従来の接触式加速度計の計測結果を基にはん用 構造解析ソフトで推定した応力，およびひずみゲージ 式と比較して同程度であることがわかる。また，面外 振動のみからの推定精度 (計測角度 $25^{\circ}$ ) と, 面外・面 内同時計測からの推定精度 (計測角度 $15^{\circ}$ ) は同程度で

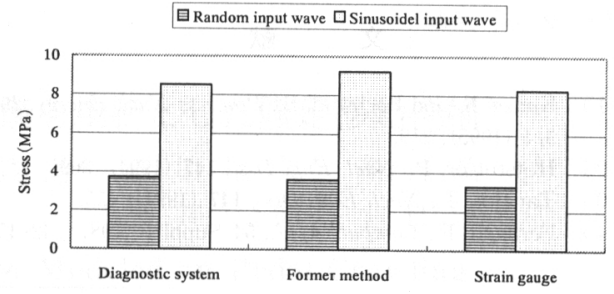

(a) Estimated stress with in-plane and out-of-plane vibrometer (inclination angle $15^{\circ}$ )

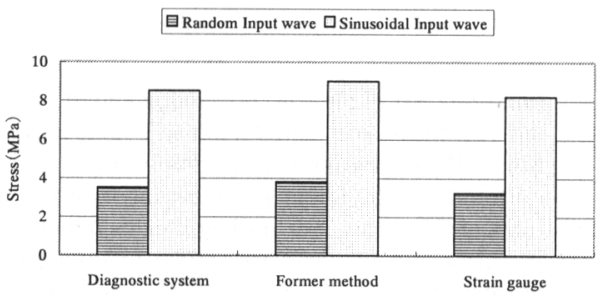

(b) Estimated stress with out-of-plane vibrometer (inclination angle $25^{\circ}$ )

Fig. 14 Estimated stress of pipe branch by each method あり，振動モードさえ特定できれば，面外振動計測だ けでも十分な評価が可能である.

\section{5. ま と め}

小口径分岐管を対象とした非接触高サイクル疲労診 断システムを開発した。主な内容を以下に列挙する。

（1）面外振動についてはドップラー振動計，面内 振動に対してはスペックル振動計を採用することによ り, 非接触にて配管振動を計測するセンシング手法を 確立した。

（2）検証試験結果では, 診断システムより解析モ デルを介して計測データと発生応力の伝達関数から求 められた発生応力は従来手法により求められた発生応 力とほほ同程度であり, 診断システムの有用性を確認 することができた。

（3）非接触センシング部の移動としてはモノレー ル等による移動手段を想定しており, 実機導入に際し てはセンシング部の小形化, およびモノレール等の移 動装置の開発が必要となるが, プロトタイプとして固 定式の非接触高サイクル疲労診断システムを開発し た.

（4）本高サイクル疲労診断システムを採用するこ とにより，分岐管の不適合事象を未然に防止できるほ か, 配管系の補修期間の短縮, 定期検査の合理化を図 ることができ, プラントの安全性, 信頼性向上に寄与 することが可能であると考えられる. 


\section{文献}

(1) Kunze, K. and Bechtold, B., Progress Nucl. Energy, 293/4 (1995), 219.

(2) Hofstotter, P., Nucl. Eng. Des., 147 (1994), 369.

(3) Tanaka, T., Nucl. Eng. Des., 147 (1994), 455.

(4) Fernand, F., Comput. Appl., 54-Suppl 1 (1987), 42-45.
(5) Bauernfeind, V., Nucl. Eng. Des., 133 (1992), 17.

(6) Tomonaka, T., ほか 4 名, Mitubishi Heavy Ind. Tech. J., 34-6 (1997), 1.

(7) ASME Code Section III, Division I, Appendix I, (1992).

(8) NRIM (National Research Institute of Material, Japan), Fatigue Data Sheet No. 5 (1989). 